\title{
O DESENVOLVIMENTO DE CAPACIDADES AUTOAVALIATIVAS DOCENTES: META A SER ALCANÇADA NA FORMAÇAO CONTINUADA DE PROFESSORES
}

\author{
Elvira Lopes Nascimento é docente do Dept de Letras Clássicas e Vernáculas e do Programa de Pós-Graduação em Estudos da Linguagem. \\ da Universidade Estadual de Londrina. \\ E-mail: elopes@ sercomtel.com.br \\ Maria Ilza Zirondi é docente colaboradora do Dept de Letras Clássicas e Vernáculas da Universidade Estadual de Londrina. \\ E-mail: ilzamaria2000@yahoo.com.br
}

\section{RESUMO}

Neste artigo, nosso objetivo é apresentar uma proposta de organização das capacidades docentes necessárias tanto na formaçao inicial quanto na continuada e a necessidade de se desenvolver capacidades autoavaliativas nos professores em formação, a fim de que possam avaliar de maneira critica seu trabalho, suas dificuldades e as lacunas provenientes de uma formação, em alguns casos, ineficaz. Ao Analisar os discursos provenientes de um curso de formação continuada, verificamos que a geração de conflitos pode conduzir os professores em formação a repensarem sobre seus conhecimentos e reconhecerem suas falhas à busca de soluções para suas dificuldades por meio de um processo de autoavaliação permanente.

\begin{abstract}
In this article our goal is to present a proposal of the organization of teacher capacities, needed both in preservice and in-service education, and the necessity for teachers to develop self-evaluating capacities during their education so that they can critically evaluate their work, their difficulties and the gaps in their education, which is sometimes inefficient. By analyzing the discourses which arise in an in-service education course, we noticed that the emerging conflicts may prompt teachers to rethink their knowledge, recognize their faults and as a result seek for solutions to their difficulties through a constant process of selfevaluation.
\end{abstract}

\section{Introdução}

Este trabalho se situa no quadro do projeto de pesquisa Gêneros textuais: das mediações formativas aos objetos de ensino, em desenvolvimento na UEL, que articula pesquisadores em diferentes focos inerentes a intervenções formativas. Nossos dados são provenientes de um contexto de intervenção formativa para um grupo inicial de 20 professores das séries iniciais do Ensino Fundamental I em formaçao continuada da Rede Municipal de Ensino de um município próximo à cidade de Londrina/Pr. Neste artigo, temos por objetivo apresentar uma proposta de organização das capacidades docentes ( $\mathrm{CD}$ doravante) necessárias tanto na formaçao inicial quanto na continuada e a necessidade de se desenvolver capacidades autoavaliativas (CAA doravante) nos professores em formação, a fim de que possam avaliar de maneira critica seu trabalho, suas dificuldades e as lacunas provenientes de uma formação, muitas vezes, ineficaz. Para isso, apresentamos trechos do discurso entre professor formador e professores em formação, promovido durante um curso de formação continuada, a fim de demonstrar como podem principiar reflexões a respeito das CAAs. 
Vindo ao encontro das expectativas de redemocratização da gestão do ensino publico no Brasil, nossas reflexões sobre o trabalho do professor e o ensino têm abarcado o sistema educacional constitutivo da educação em seus diferentes níveis. Nesse trabalho, focalizamos a Formação de Professor da Educação Básica que, integrado ao Plano Nacional de Educação (PNE, 2010; MEC, 2005), estabelece a implantação progressiva do Ensino Fundamental de nove anos (Lei no 10.172/2001, meta 2 do Ensino Fundamental), o que torna crucial repensar esse ciclo educacional no seu conjunto. Mediante as necessidades educacionais para esta fase da escolarização, de descobertas e aprendizagens para o uso das diferentes modalidades de linguagem, aderimos à perspectiva teórica da Didática das Línguas (DOLZ, GAGNON e DECÂNDIO, 2009) - disciplina que estuda os fenômenos de ensino e aprendizagem das línguas e as relações complexas entre os três polos do triângulo didático: o professor, o aluno e a língua (ou as línguas) ensinada(s), uma vez que a práxis dos educadores, implica saberes, objetos de ensino e a sua organização para a progressão temporal, bem como os métodos de trabalho.

Coerente com a concepção interacionista da linguagem, da leitura e da escrita, Dolz (2009, p. 25), se refere à Didática das Línguas como sendo uma disciplina científica, cuja edificação "supôs e ainda requer a elaboração de um sistema conceitual e uma reflexão sobre suas relações com as disciplinas de referência, particularmente com as ciências da linguagem e com a psicolingüística". Portanto, é uma disciplina emergente que, segundo o autor, se insere tanto "no campo da teoria e no campo das práticas didáticas escolares, dependendo tanto de sua capacidade para gerar novos saberes quanto para resolver os problemas sociais e educativos". (Dolz, 2009, p.31 destaque nosso).

Nessa perspectiva, o foco destas investigações têm sido a engenharia didática e as práticas dos professores (Dolz, 2009) no contexto escolar da educação fundamental. As mediações formativas, portanto, orientadas por essas duas possibilidades, insere às salas de aula o ensino baseado nos gêneros textuais que, quando utilizados em situações de formação continuada, podem ser instrumentos para promover a construção de saberes e o desenvolvimento de $\mathrm{CD}$ dos professores em formação - tema principal deste artigo.

\section{Aportes teóricos na busca por compreender a complexa relação entre os saberes profissionais e trabalho}

No quadro do interacionismo sociodiscursivo - ISD (Bronckart, 1999; 2006; 2008), são fundamentais as discussões sobre as relações entre a linguagem, conhecimento e desenvolvimento humano. Do ISD emerge a tese de que os gêneros de textos, enquanto formatos linguageiros de comunicação, propiciam a evolução humana, dando condições para que os indivíduos se desenvolvam cognitiva e psicologicamente. Para tentar explicar essa complexa relação entre a linguagem e o desenvolvimento, essa vertente teórica considera a necessidade de uma abordagem pluridisciplinar, sem a qual não podemos compreender os fenômenos especificamente humanos. 
Em síntese, os princípios gerais do ISD (Bronckart, 1999) constituem o projeto de uma ciência do humano reunificada (em reação à fragmentação herdada do positivismo), uma ciência de intervenção (capaz de medir a validade do conhecimento que produz pela capacidade de transformação ou operacionalização prática); uma ciência sustentada (permanentemente) pela reflexão epistemológica (susceptível de repensar modelos e dados), especificamente, científica; uma ciência natural (que rejeita a oposição entre ciências naturais e ciências humanas) em função da adesão aos princípios de Spinoza (monismo materialista e paralelismo psicofisiológico - Coutinho, 2009).

O projeto do ISD é o de implementar um programa de trabalho (Bronckart, 1999; 2006) que busca desenvolver-se em três vertentes, de forma descendente, dialética: a) análise das características dos pré-construídos históricos, sociais e culturais; b) análise dos processos de mediação sociossemiótica através dos quais crianças e adultos se apropriam desses pré-construídos; c) análise dos efeitos dos processos de apropriação (sobre a constituição da pessoa consciente e/ou sobre o desenvolvimento ao longo da vida e sobre a capacidade de intervenção, ou transformação, dos préconstruídos).

Para tratar das questões relacionadas à análise dos textos/discursos em seus níveis: semântico, enunciativo e organizacional (Machado e Bronckart, 2009; Bulea, 2010), outros autores e aportes se fizeram necessários, tais como o trabalho voltado ao ensino de gêneros na escola, o de construção/elaboração de sequências didáticas e o desenvolvimento das Capacidades de Linguagem (Schneuwly; Dolz, 2004) e sobre o trabalho do professor (Machado, 2004; 2009; 2011).

\subsection{As Capacidades Docentes: um conceito amplo e complexo em discussão}

Segundo Dolz e Schneuwly (2004), a compreensão e produção de gêneros textuais requerem dos alunos o desenvolvimento de capacidades de linguagem que se referem a aptidões requeridas do aprendiz para a produção de um gênero numa situação de interação determinada. Os autores destacam três capacidades de linguagem:

- Capacidades de ação (CA) que estão relacionadas com as representações ou conhecimentos mobilizados pelo indivíduo para o reconhecimento do gênero, seu contexto de produção (produtor, receptor, local de produção, posição social ocupada pelo produtor e receptor, etc.), e os conteúdos mobilizados. O desenvolvimento das CA possibilita aos sujeitos uma melhor compreensão dos aspectos da interação comunicativa: os objetivos de comunicação, conteúdo referencial, os agentes da enunciação, o ambiente físico, os papéis sociais, o momento de produção, etc.

- Capacidades discursivas (CD) relacionam-se com as representações ou conhecimentos mobilizados sobre as características próprias do gênero quanto a sua arquitetura textual/estrutura organizacional. O seu desenvolvimento possibilita uma melhor organização do discurso de acordo com os objetivos de comunicação do enunciador e de acordo com o contexto em que se está inserido. 
- Capacidades linguístico-discursivas (CLD) estão relacionadas ao reconhecimento das unidades linguísticas do gênero, ou seja, o entendimento das operações linguísticas necessárias à produção do gênero, realizadas por meio da mobilização dos níveis da arquitetura textual: mecanismos de textualização (conexão e coesão verbal e nominal) e mecanismos enunciativos (vozes, modalizações e as escolhas lexicais).

A essas três capacidades de linguagem, Cristóvão e Stutz (2011) propõem uma expansão desse grupo a uma quarta capacidade, chamada de Capacidade de Significação (CS). De ordem mais praxiológica, isto é, relativa à atividade geral, abarca a construção de representações e/ou conhecimentos sobre as práticas sociais (contexto ideológico, histórico, sociocultural, econômico, etc.) que envolvem esferas de atividade e conteúdos temáticos de diferentes experiências humanas.

Todas as Capacidades de Linguagem estão estritamente relacionadas à aquisição de saberes e a aprendizagens que buscam averiguar se houve desenvolvimento ou não dos indivíduos durante os processos formativos. No caso da formação de professores, segundo Quevedo-Camargo (2011), a aquisição e/ou desenvolvimento dessas capacidades estão atrelados a algo mais global como as Capacidades Docentes.

Para Feldman (2012), as CDs são capacidades básicas de um docente, como o uso de estratégias pertinentes, técnicas e habilidades características de um bom desempenho. Para o autor, "las capacidades suponem um conjunto relativamente localizado de instrumentos categorias y habilidades que admitem distintas realizaciones, frente a um tipo de problemas y de acuerdo com situaciones específicas". Já para Stutz (2012), ao se referir à formação inicial de professores, menciona que as CDs guiam o trabalho de formação inicial, visto que trazem especificidades sobre os saberes que precisam ser transformados, pois são capazes de construir ou modificar operações psíquicas. Segundo a autora, a construção de CDs durante o processo de formação, portanto, se constitui como uma base sólida para que, no futuro, o professor se aproprie dos diversos saberes relacionados ao métier do professor. Esses saberes, segundo Hofstetter e Schneuwly (2009) são saberes a ensinar: que são os saberes utilizados como objeto de trabalho do professor para ensinar; saberes para ensinar: que são os saberes que constituem o instrumento de trabalho do professor. Ambos se relacionam aos métodos, às abordagens, aos dispositivos, assim como aos planos de estudos, instruções, finalidades, estruturas administrativas e políticas (Hofstetter; Schneuwly, 2009)

Sob essa perspectiva, vamos discutir essa problemática que envolve a aquisição desses saberes em relação à formação continuada. Primeiro, partiremos daquilo que é considerado como atividade profissional do professor. No quadro do materialismo dialético no qual se insere o ISD, a atividade humana (Leontiev, 1978) se constitui a partir de conjunto de ações voltadas para sua realização, isto é, a atividade é um fim ou resultado de várias ações constitutivas dessa atividade. Assim, cada ação empenhada pelo professor e que se relaciona de alguma forma com o ensino/aprendizagem constitui a atividade profissional docente (Machado, 2004). Entretanto, essas ações a serem 
desempenhadas devem ter um significado atribuído à consciência de seu agir profissional, o que implica a apropriação de uso dos instrumentos (Friedrich, 2012), visando ampliar e sistematizar a compreensão da realidade, caracterizando, assim, o trabalho docente com a prática educativa escolar.

Essas ações conscientes estão estritamente relacionadas aos saberes do professor. Tardif (2008) menciona que esses conhecimentos são acessados durante a ação do professor e se estabelecem como saberes docentes. Segundo o autor, estes saberes são a confluência de vários saberes provenientes dos mais variados contextos, como da sociedade, da instituição escolar, dos setores educacionais, das universidades etc.

Para Bronckart (2006), esses saberes, assim como as competências etc., considerados como conhecimentos, são úteis para o desenvolvimento humano, pois o saber-fazer está atrelado às capacidades pretendidas. Ou seja, o autor considera as competências como propriedades do organismo humano, que, estendidas às capacidades dos indivíduos e adaptadas ao meio nas práticas sociais, em interação com um grupo, são exigidas de um sujeito e avaliadas de acordo com a sua performance. Assim, nas atividades coletivas de trabalho é que se pode deduzir quais competências a serem avaliadas se são ou não satisfatórias e se um sujeito é realmente capaz.

Consideramos, assim, que as competências (competencial - Bronckart, 2006, p.199) têm estreita relação com capacidades. Essas são averiguadas em situação de ação, isto é, os sujeitos ao realizarem determinadas tarefas se utilizam de suas propriedades dinâmicas intrínsecas para (re)produzir, transferir, adaptar, (re)criar, deslocar, explorar, (re)introduzir etc. os saberes previamente adquiridos, competências desenvolvidas, para uma nova situação que exige um agir. Desta forma, aferimos ao processo de desenvolvimento de um indivíduo a aquisição e desenvolvimento de competências e, as capacidades como produto revelado pelas ações realizadas de maneira "satisfatória". Contudo, não se trata de uma linha divisória entre ambos, pois são indissociáveis, à medida que um complementa o outro dentro de um processo contínuo do desenvolvimento humano.

Nesse sentido, consideramos que a CD implica ser capaz de reconhecer a escola como uma organização complexa, cuja função é promover a educação para a cidadania, tendo por base a pesquisa, a análise e a busca por mudar os resultados educacionais; a CD diz respeito à participação ativa na gestão dos processos educativos e na organização e funcionamento de sistemas e instituições de ensino; a CD é conceber a docência como prática social educativa, pedagógica, interdisciplinar que integre teoria e prática ao ensino, pesquisa e extensão.

Assim, o docente deve ser capaz de construir novas relações de trabalho na escola; de enfrentar coletivamente as condições objetivas e subjetivas que obstaculizam o aprendizado escolar; de estabelecer o estudo constante teórico-metodológico à busca de novas relações entre teoria e prática; de valorizar as experiências à busca de solucionar problemas com seus pares; de refletir de maneira critica sobre sua própria pratica a fim de reformular suas ações de maneira continua; de buscar compreender o 
significado de seu trabalho; de defender/lutar por melhores condições, tanto da sua profissão, quanto da escola em relação aos recursos físicos/materiais, didáticos, organizacionais, de gestão de salário etc.. Para isso, cabe ao professor formador de professores organizar metodologicamente os cursos de formação continuada para desenvolver nos professores em formação essas capacidades. Nesse sentido, a busca por tornar eficientes os CFs, diferentes ações devem ser implementadas,, tanto na formação inicial quanto na continuada, considerando-se as distinções entre os contextos que por sua diversidade requerem estratégias interventivas específicas e pontuais.

Diante disso, consideramos a formação inicial e a formação continuada como dois momentos distintos da formação profissional docente que, metodologicamente, chamaremos de capacitação docente inicial e capacitação docente continuada. Enquanto a primeira se refere à formação inicial e às capacidades necessárias para o exercício da profissão no futuro, a segunda diz respeito à formação continuada e à reflexão e revisão das ações em curso.

\section{Uma proposta de organização das CDs}

Diante do exposto, assumimos os riscos e propomos um quadro daquilo que poderíamos chamar de CDs anteriores à ação de ser professor (desenvolvidas durante a formação inicial) e CDs posteriores à formação inicial (ações desenvolvidas durante o processo de ensino). Primeiramente, apresentaremos uma proposta com base em reflexões apresentadas para nomeação das capacidades docentes que "profissionalizam" o professor e, depois, de capacidades docentes que "aperfeiçoam" essa formação.

Feldman (2012), por exemplo, apresenta trinta e seis capacidades para a atividade docente em escolas da educação básica. $\mathrm{O}$ autor divide essas capacidades em seis categorias ${ }^{1}$ que se relacionam aos: 1 ) aspectos interativos do ensino (como a gestão da classe, metodologia e auxílio pedagógico às dificuldades dos alunos); 2) planificação (preparação das unidades de trabalho); 3) desempenho (no que se refere à evolução dos alunos no desenvolvimento das atividades e das aulas); 4) dinâmica grupal (para o funcionamento e participação do grupo); 5) organização e disciplina (como se estabelecer normas e regras de convivência); 6) atividade institucional (diz respeito às relações e atividades desenvolvidas junto à equipe, à instituição e à comunidade).

Essa organização proposta por Feldman, no entanto, não distingue a formação inicial da continuada, fato que consideramos importantíssimo para a formação profissional docente, pois auxilia na organização dos CFs e das necessidades dos professores. Esses aspectos de ordem formativa, e que devem ser as CDs apresentadas por um formando, nem sempre, na prática, poderão ser considerados de tal forma. Gagnon (2010, p. 21/22) aponta para o fato de a profissionalização e o profissionalismo nem sempre estarem conjuntos no exercício docente. Segundo a autora, a profissionalização corresponde aos saberes e competências necessários à prática de

\footnotetext{
${ }^{1}$ Tradução nossa.
} 
métier. Já, o profissionalismo corresponde à divisão do trabalho com um grupo profissional e a avaliação das estratégias utilizadas para valorizá-lo (tradução nossa). Consideramos, assim, que, a profissionalização corresponda às CDs adquiridas durante a formação inicial e o profissionalismo às CDs adquiridas/desenvolvidas durante o exercício da profissão docente, seja pela experiência, seja pela formação continuada.

Diante disso, iremos propor algumas CDs para a formação inicial e, posteriormente, CDs para a formação continuada. Para isso, Partiremos de alguns pressupostos das Diretrizes Curriculares para a Formação de Professores (2001), que estabelecem como prioridade para Cursos de graduação e para a formação do futuro professor, deixando claro apenas, que essa é uma sugestão de organização das CDs e que não se esgotam e nem se fecham para criticas e discussões:

Quadro 1: Capacitação Docente: Capacidades e saberes docentes na formação inicial

\begin{tabular}{|c|c|}
\hline $\begin{array}{c}\text { CAPACIDADES DOCENTES A SEREM } \\
\text { ADQUIRIDAS DURANTE } \\
\text { A FORMAÇÃO INICIAL }\end{array}$ & SABERES \\
\hline $\begin{array}{l}\text { 1. Orientar e mediar o } \\
\text { ensino para a aprendizagem dos } \\
\text { alunos }\end{array}$ & $\begin{array}{l}\text { • Dominar por meio de } \\
\text { atividades orais e/ou escritas conteúdos } \\
\text { voltados para a(s) disciplina(s) e prática } \\
\text { de sala de aula; } \\
\text { • Associar teoria à } \\
\text { prática; } \\
\text { ensino por meio do estágio; } \\
\text { • } \\
\begin{array}{l}\text { esquematizar, planificar, } \\
\text { conteúdos; }\end{array} \\
\text { ensino. }\end{array}$ \\
\hline $\begin{array}{c}\text { 2. Comprometer-se com } \\
\text { o sucesso da aprendizagem dos alunos }\end{array}$ & $\begin{array}{l}\bullet \text { Reconhecer } \\
\text { dificuldades do contexto e individuais; } \\
\bullet \quad \text { Elaborar atividades } \\
\text { diversificadas; } \\
\bullet \quad \text { Conhecer a sócio- } \\
\text { história do grupo e a individual; } \\
\bullet \quad \text { Reconhecer } \\
\text { problemas individuais e buscar/orientar } \\
\text { para soluções pontuais; } \\
\bullet \quad \text { Envolver a família no } \\
\text { processo aprendizagem; }\end{array}$ \\
\hline $\begin{array}{l}\text { 3. Assumir e saber lidar } \\
\text { com a diversidade existente entre os } \\
\text { alunos }\end{array}$ &  \\
\hline \multicolumn{2}{|c|}{$\begin{array}{c}\text { Revista Escrita } \\
\text { Rua Marquês de São Vicente, 225 Gávea/RJ CEP 22453-900 Brasil } \\
\text { Ano 2012. Número 15. ISSN 1679-6888. } \\
\text { escrita@ puc-rio.br }\end{array}$} \\
\hline
\end{tabular}




\begin{tabular}{|c|c|}
\hline & estigmatizadores e preconceituosos. \\
\hline $\begin{array}{l}\text { 4. Incentivar atividades } \\
\text { de enriquecimento cultural }\end{array}$ & 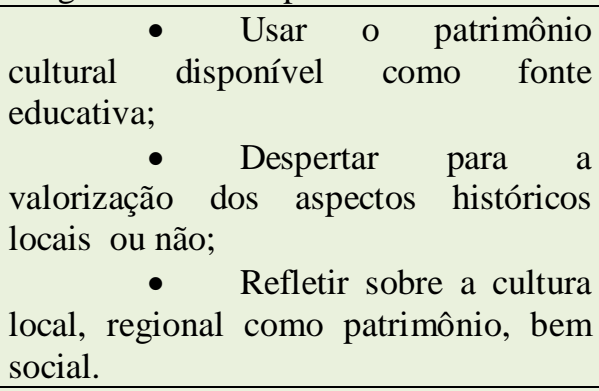 \\
\hline $\begin{array}{cc}5 . & \text { Desenvolver práticas } \\
\text { investigativas } & \end{array}$ & 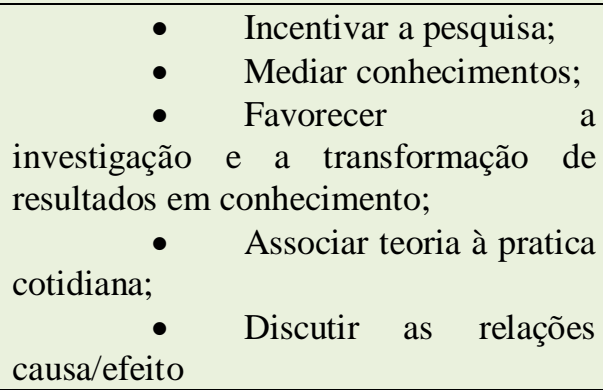 \\
\hline $\begin{array}{l}\text { 6. Elaborar e executar } \\
\text { projetos para desenvolver conteúdos } \\
\text { curriculares }\end{array}$ & 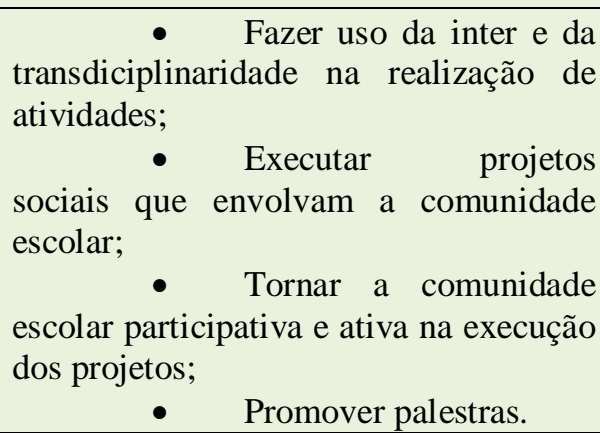 \\
\hline $\begin{array}{l}\text { 7. Utilizar novas } \\
\text { metodologias, estratégias e materiais } \\
\text { de apoio }\end{array}$ & $\begin{array}{llr}\bullet & \text { Utilizar } & \text { recursos } \\
\text { multimídia; } & & \\
\bullet & \text { Propiciar a manipulação } \\
\text { de objetos de laboratório, informática, } \\
\text { outros recursos; } \\
\bullet \quad \text { Elaborar } \\
\text { diferenciados }\end{array}$ \\
\hline $\begin{array}{c}\text { 8. } \quad \text { Desenvolver hábitos } \\
\text { de colaboração e trabalho em equipe }\end{array}$ & 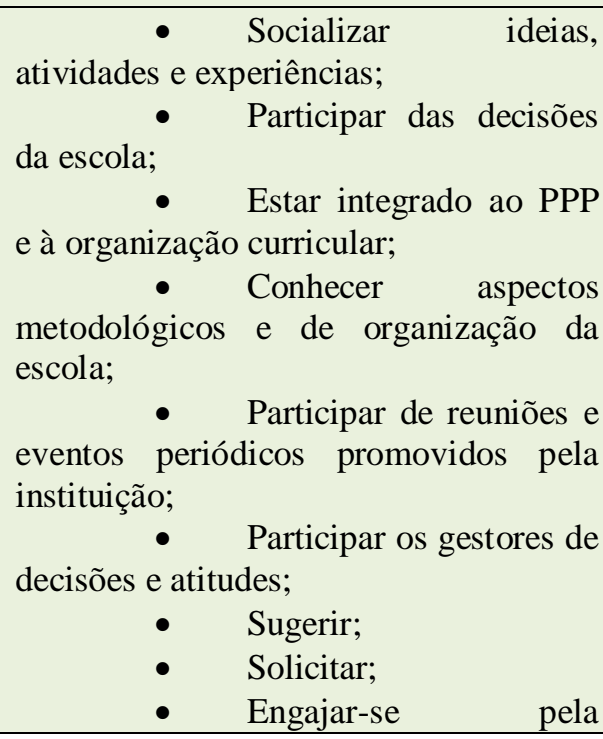 \\
\hline \multicolumn{2}{|c|}{$\begin{array}{c}\text { Revista Escrita } \\
\text { Rua Marquês de São Vicente, 225 Gávea/RJ CEP 22453-900 Brasil } \\
\text { Ano 2012. Número 15. ISSN 1679-6888. } \\
\text { escrita@ puc-rio.br }\end{array}$} \\
\hline
\end{tabular}




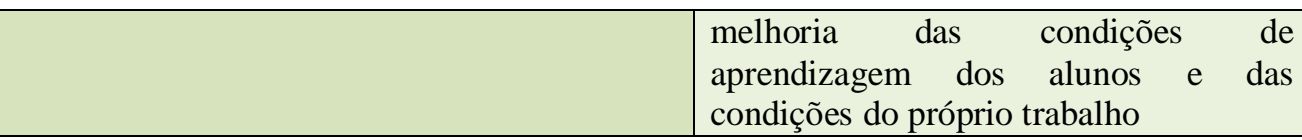

Essas CDs, a nosso ver, estão atreladas àquilo que Quevedo-Camargo (2011) utilizou como base para a sua proposta de avaliação para a formação de professores em Língua Inglesa. Para Quevedo-Camargo, durante a formação são realizados conjuntos de operações que permitem que as ações de linguagem funcionem como instrumento para mobilizar os conhecimentos necessários para a aprendizagem docente. Como proposta, a autora sugere quatro níveis para a avaliação profissional: capacidade de ação docente, capacidade discursiva docente, capacidade linguístico-discursiva docente e capacidade de auto-gestão. Concebemos, assim, que essas CDs são adquiridas, principalmente, durante a formação inicial e que se aperfeiçoam durante os processos de exercício da profissão (experiências) e pela formação continuada.

A esses processos, inserimos outro que achamos de extrema importância e relevância: a capacidade de autoavaliação permanente. Ao desenvolver essa capacidade, por meio de atos reflexivos, o professor reconhece suas falhas, sejam elas relacionadas às mais diferentes necessidades do contexto e dos saberes necessários para a docência.

Desta forma, durante os processos de formação inicial, um dos aspectos preponderantes para a capacitação docente deve ser o desenvolvimento da Capacidade Docente Autoavaliativa (CAA), pois é a partir dessa que o professor em exercício sentirá quais as suas necessidades/deficiências em relação aos aspectos apontados por Feldman (2012), como a gestão de sala de aula, auxílio pedagógico, planificação, inovação das aulas, dinâmica de grupo, disciplina e organização e desempenho institucional que estão relacionados aos aspectos de ensino apontados por Gagnon $(2010, \text { p. } 110)^{2}$ :

"les finalités sociales de l'enseignement; 2. les connaissances, le développement et les modes d'apprentissage des eleves; 3. l'institution (les prescriptions officielles); 4. les méthodes d'enseignemen; 5. les savoirs sur les pratiques professionnelles".

Porém, o objeto do qual tratamos se refere à formação continuada e é justamente em torno de como desenvolver, ampliar ou aperfeiçoar as CDs, consequentemente, o desenvolvimento do professor, que envolve nossa problemática. Baseados no quadro apresentado por Stutz (2012), buscamos nos saberes apontados pela autora como inerentes à formação inicial para a Capacitação Docente - como a capacidade de compreender/verificar aspectos contextuais; capacidade de avaliar/analisar metodologias; capacidade de selecionar/produzir recursos; capacidade de planificar as

\footnotetext{
2 1) As finalidades sociais do ensino; 2) os níveis de conhecimentos, de desenvolvimento e dos modos de aprendizagem; 3) a instituição (as prescrições oficiais); 4) os métodos de ensino; 5) os saberes sobre as práticas profissionais. (traduçao nossa) 
aulas; capacidade de reger; capacidade de contribuir/construir autonomia; capacidade de avaliar a aprendizagem - um ponto de partida para nossa reflexão.

A partir das reflexões em Feldman (2012), Stutz (2012) e Gagnon (2010) elaboramos um quadro que busca organizar, a partir da proposta de desenvolvimento das Capacidades de Linguagem Docente (Quevedo-Camargo, 2011) adquiridas durante a formação inicial, as CDs do professor em exercício, da seguinte maneira:

Quadro 2: Capacidades docentes na formação continuada

\begin{tabular}{|c|c|}
\hline $\begin{array}{l}\text { CAPACIDADE DE LINGUAGEM } \\
\text { DOCENTES }\end{array}$ & CAPACIDADES DOCENTES \\
\hline 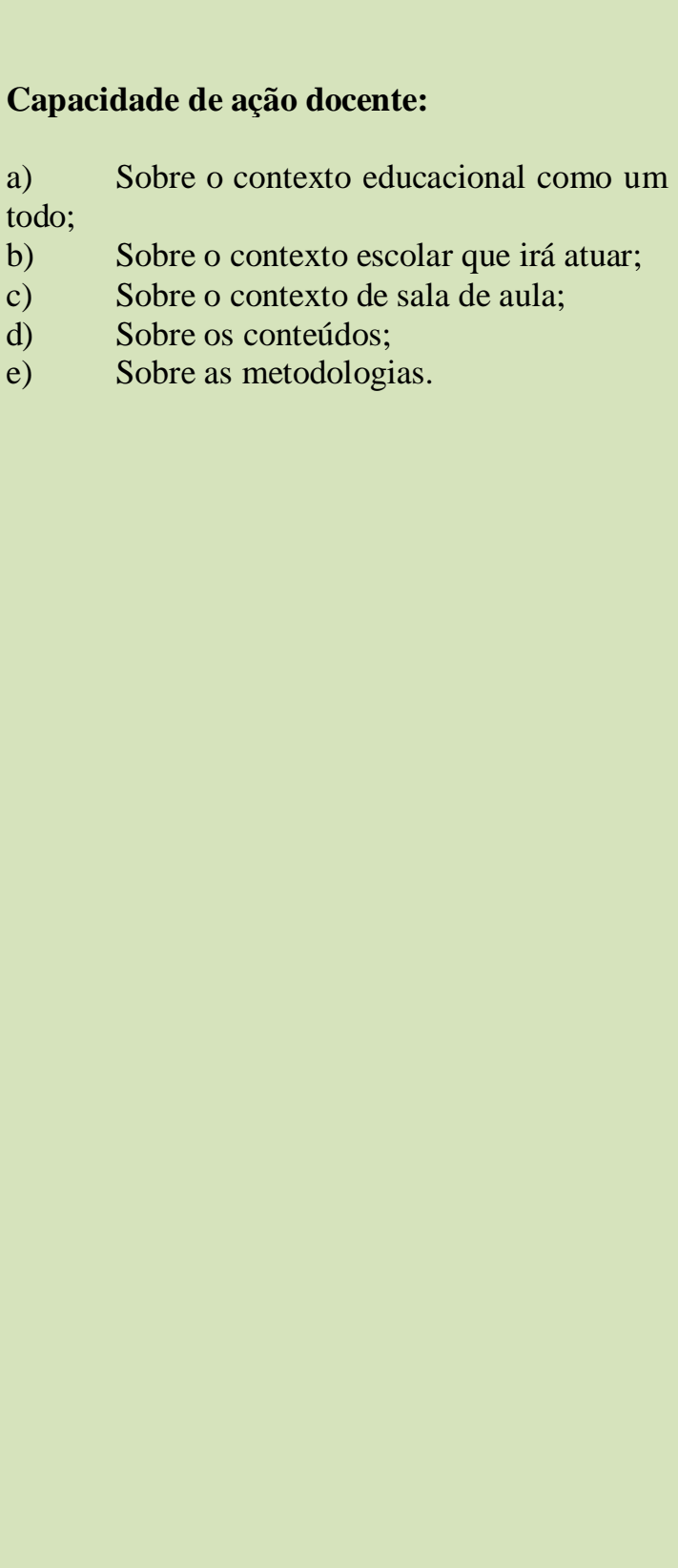 & 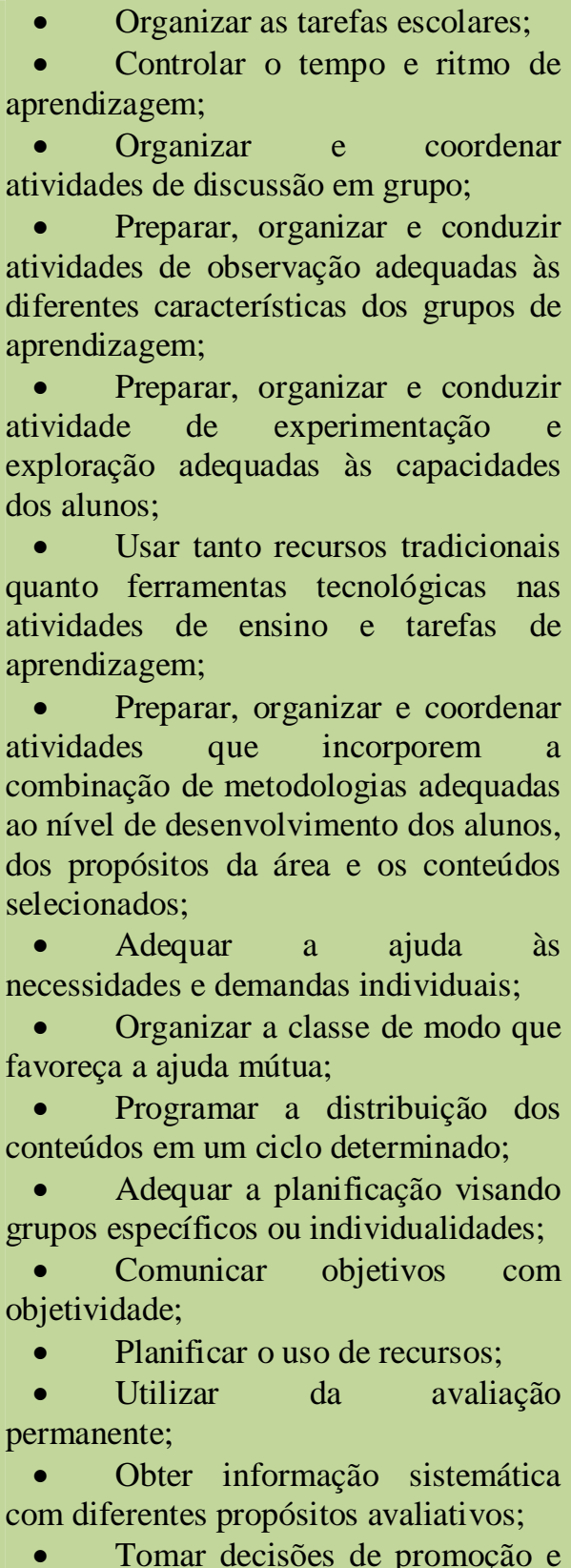 \\
\hline
\end{tabular}




\begin{tabular}{|c|c|}
\hline & $\begin{array}{l}\text { orientação; } \\
\qquad \quad \text { Promover condições de } \\
\text { trabalho; } \\
\bullet \quad \text { Estabelecer pautas e regras de } \\
\text { convivência; }\end{array}$ \\
\hline $\begin{array}{l}\text { Capacidade linguísticas docente: } \\
\text { a) Sobre a organização interna e } \\
\text { apresentação dos documentos oficiais e das } \\
\text { prescrições; } \\
\text { b) Sobre os conteúdos específicos a serem } \\
\text { trabalhados; } \\
\text { c) Sobre a diversidade de textos e sua } \\
\text { organização linguística; } \\
\text { d) Sobre formas de comunicação } \\
\text { adequadas à turma e à série; } \\
\text { e) Sobre escolhas e organização de } \\
\text { material; } \\
\text { f) Sobre os recursos (multimeios) a serem } \\
\text { utilizados; } \\
\text { g) ... }\end{array}$ & $\begin{array}{l}\text { • Dirigir questões didáticas } \\
\text { orientadas; } \\
\text { - Intervir em situações de trocas } \\
\text { entre alunos; } \\
\text { - Dirigir questões apropriadas; } \\
\text { - Usar da diversidade textual; } \\
\text { - Realizar exposições teóricas } \\
\text { breves sobre temas distintos; } \\
\text { - Preparar, organizar e coordenar } \\
\text { atividades que promovam a formação de } \\
\text { categorias, conceitos e, principalmente, } \\
\text { adequadas ao nível de desenvolvimento } \\
\text { dos alunos em distintas áreas de ensino; } \\
\text { - Desenvolver } \\
\text { mediante demonstração (modelo para } \\
\text { ação); } \quad \text { Favorecer a comunicação; } \\
\text { - } \quad \text { Dominar e utilizar com } \\
\text { - } \quad \text { cordades } \\
\text { pertinência, um repertório de técnicas } \\
\text { lúdicas e técnicas em grupo; } \\
\text { - Trabalhar e enfrentar conflitos } \\
\text { em grupo; } \\
\text { - Formar hábitos e atitudes; }\end{array}$ \\
\hline $\begin{array}{l}\text { Capacidade linguístico-discursiva docente: } \\
\text { a) Sobre as interpretações e compreensão } \\
\text { dos documentos oficiais e das prescrições; } \\
\text { b) Sobre discursos estigmatizadores e } \\
\text { preconceituosos; } \\
\text { c) Sobre a diversidade verbal em sala de } \\
\text { aula advinda da linguagem oral dos alunos; } \\
\text { d) Sobre o material a ser utilizado; } \\
\text { e) Sobre as metodologias propostas; }\end{array}$ & $\begin{array}{l}\text { - Guiar atividades baseadas na } \\
\text { formulação e resolução de problemas; } \\
\text { - Utilizar diversidade discursiva; } \\
\text { - Utilizar distintas formas de } \\
\text { representação da informação nas } \\
\text { atividades de ensino e nas tarefas de } \\
\text { aprendizagem; }\end{array}$ \\
\hline $\begin{array}{l}\text { Capacidade autoavaliativa docente: } \\
\text { a) Sobre os (auto)conhecimentos } \\
\text { relacionados às prescrições e aos documentos } \\
\text { oficiais; } \\
\text { b) Sobre os conteúdos teóricos; } \\
\text { c) Sobre as metodologias de ensino; } \\
\text { d) Sobre avaliação; } \\
\text { e) Sobre a regência da sala; } \\
\text { f) }\end{array}$ & $\begin{array}{l}\text { - refletir quais as concepções } \\
\text { sobre os contextos; } \\
\text { - Refletir sobre quais as relações } \\
\text { entre teoria e prática; } \\
\text { - Refletir sobre atitudes e } \\
\text { comportamentos próprios frente a } \\
\text { diferentes situações; } \\
\text { - Refletir sobre suas próprias } \\
\text { ideologias e formas de pensar; } \\
\text { - Refletir sobre suas próprias }\end{array}$ \\
\hline
\end{tabular}




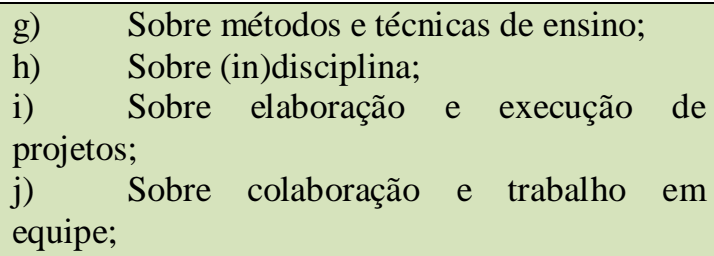

ações;

- Refletir sobre suas dificuldades em relação aos conteúdos;

- Refletir sobre suas dificuldades em relação ao manejo da turma e a problemas gerados por conflitos;

- Refletir sobre as metodologias utilizadas em relação ao aproveitamento da turma;

- Refletir sobre o conhecimento em relação às novas tendências ou metodologias;

- Refletir sobre o domínio dos conteúdos teóricos e sua aplicação na prática;

- Refletir sobre o uso de novas ferramentas de ensino e o uso das tecnologias;

- Refletir sobre os valores culturais e sociais e os modos de transmiti-los.

Buscamos sugerir na apresentação dos quadros, que na formação inicial (quadro 1), os saberes a serem apreendidos pelos alunos sejam pensados como objetivos de ensino para os cursos que os ofertam e que, na formação continuada (quadro 2), a capacidade de autoavaliação possa se tornar um instrumento de medição de como essas capacidades docentes adquiridas durante a formação inicial estão sendo postas em prática. O próprio professor ao se autoavaliar determina os pontos falhos em sua formação e, de maneira consciente, - e não imposta pelos órgãos educacionais como geralmente ocorre - possa buscar sanar essas "falhas", aprimorar ou aperfeiçoar seu agir pedagógico.

Há de se pensar aqui, que baseados nos aspectos que propomos como condicionantes para cada grupo de capacidade - capacidade de ação docente; capacidade linguística docente; capacidade linguístico-discursiva docente - os cursos a serem implementados ou programados poderiam se voltar aos aspectos relacionados a essas capacidades. Dessa forma, os programas de formação, talvez, possam contribuir para uma formação continuada mais efetiva e eficaz frente às dificuldades assumidas pelos próprios professores, oferecendo cursos de formação contínua focados em problemas mais pontuais e reais e que esses possam se autoavaliar à busca daquilo que seja mais significativo e prioritário para cada um.

\section{A primeira produção como diagnóstico das CDs}

O interacionismo sociodiscursivo concebe a linguagem como tendo um papel fundamental no desenvolvimento psíquico humano e os textos é que revelam as representações (Habermas, 1989) que cada um constrói sobre seu próprio agir e sobre o 
agir do outro, assim, somente por meio da interpretação das ações verbais se é possível compreender as ações humanas. Dessa forma, menciona Machado (2011, p. 20), "as produções textuais se constituem o meio pelo qual se constroem as representações sociais e racionais que permitem que os indivíduos se situem e julguem cada contribuição particular para a realização das atividades sociais". Tal construção, afirma a autora, se dá nas atividades sociais, reguladas e mediadas por interações verbais, o agir comunicativo, em negociações permanentes (frequentemente conflituosas) entre as avaliações do outro e a representação que o indivíduo tem de si mesmo (Machado, 2011, p.20).

As representações (Bronckart, 2006) são traços internos (imagens mentais, ideias, sentimentos etc.) das interações dos seres humanos com o mundo. Assim, as capacidades do homem em representar são o produto da interiorização das formas de interação desenvolvidas ao longo da história e resultam da necessidade e da negociação entre os indivíduos, de acordo com seu papel social, para organizar as tarefas a serem realizadas em cada situação de comunicação.

Nesse tópico, apresentaremos uma reflexão sobre as CDs, a partir de trechos de uma primeira produção utilizada como diagnóstico em um curso de formação continuada. A análise que apresentaremos corresponde à primeira produção realizada pelas professoras em relação à Sequência Didática (SD). Os trechos a serem analisados doravante constituem-se como parte desse processo de interação, cujas trocas entre professor formador (PF) e professores em formaçao continuada (PFC), baseadas nos conflitos gerados, podem resultar na interpretação e compreensão do agir dos sujeitos envolvidos e, consequentemente, no desenvolvimento, não só dos docentes, mas do processo educacional, uma vez que evidenciam características inerentes aos processos formativos e às representações humanas construídas anteriormente ou durante a sua realização.

\subsection{A proposta}

A primeira produção constitui, no quadro teórico que adotamos, o momento de elaboração do primeiro texto, pois é por meio deste que os PFCs revelam quais as suas representações a respeito daquilo que nos propomos a fazer. Neste caso em específico, a produção de um texto inicial se refere à SD como objeto de diagnóstico, "pois permite circunscrever as capacidades de que os alunos já dispõem e, consequentemente, suas potencialidades" (Dolz, Noverraz e Sschneuwly, 2004, p. 101). A ideia da SD como instrumento de avaliação desses conhecimentos e não o modelo didático de gênero (MDG) emerge do próprio contexto, quando os professores, ao serem questionados sobre a elaboração da SD, mencionarem que já o fazem em sua rotina. A questão é que justamente detectamos que o que elas realizam corresponde a uma sequência de atividades relacionadas a um determinado gênero, ignorando, completamente, a construção de um MDG como norteador da SD. 
Em reuniões anteriores a essa proposta, apresentamos enfaticamente a necessidade do uso do modelo didático para a realização da $\mathrm{SD}$, consequentemente, sua transposição. Mas, ao percebermos que a maioria não compreendia o que significava ou qual a importância desse MDG para a teoria que propomos, utilizamos a seguinte estratégia para tornar consciente o uso desse instrumento de trabalho:

$\left.\mathbf{1}^{\mathbf{0}}\right)$ Fornecemos as informações necessárias (comando) para a produção da SD: a) Pressupostos do ISD; b) Noções sobre texto, gênero e discurso; c) Atividades com sequências discursivas e tipológicas; d) Discussão teórica sobre MDG e SD.

$\mathbf{2}^{\mathbf{0}}$ ) Apresentamos uma proposta coletiva para a produção da $\mathrm{SD}$; a) Apresentamos três textos desconstextualizados: uma biografia de Airton Senna, uma imagem do piloto e um poema (Infância de Carlos Drummond de Andrade).

$3^{\circ}$ ) Separamos os grupos (duplas ou trios) para permitir a troca de experiências, informações e conhecimentos;

$4^{\mathbf{0}}$ ) Atribuímos o comando:

\section{TRECHO 1:}

PF - Um desafio que é preparar uma aula com material X, tá? Eu vou passar pra vocês o material, eu simplifiquei bastante porque a gente não tem muito tempo aqui pra ficar lendo, relendo. Então, vamos fazer de uma maneira bem simples, mas eu acho que já é suficiente. Desse material, vamos supor que fosse o material didático que vocês encararam aquele dia pra montar sua aula, tá. [...] Que que vocês vão fazer com esse texto? Vocês vão ler, dar uma olhadinha e vão montar uma "sequência didática", ou seja, atividades como vocês fossem direcioná-las para um contexto de sala de aula específico, tá? [...]

Justificamos que o material foi apresentado de forma descontextualizada, pois isso aproxima o trabalho proposto das atividades que geralmente fazem parte da rotina das professoras, como aquelas folhas xerocadas para toda a turma com propostas que, muitas vezes, nem se relacionam com os conteúdos trabalhados. Assim, o desafio da primeira produção se caracteriza por deixar que as professoras elaborem um conjunto de atividades sobre os textos apresentados, supondo que elas exponham como produto desse trabalho suas dúvidas e que as lacunas percebidas possam servir de ponto de partida para um trabalho mais sistemático e consciente dos aspectos relacionados à SD. Ainda de acordo com Dolz, Noverraz e Schnewuly (2004, p. 101) "é assim que se definem o ponto preciso em que o professor pode intervir melhor e o caminho que o aluno tem ainda a percorrer: para nós essa é a essência da avaliação formativa".

\subsection{A Produção Inicial}

A primeira produção foi sendo apresentada pelos grupos em um misto de descrição dos aspectos veiculados pelos textos, das atividades pensadas, de dúvidas e até do percurso ou raciocínio para se chegar definição. A seguir, apresentamos um recorte da exposição realizada pelas professoras: 


\section{TRECHO 2:}

PFC 1 - Nós elencamos várias atividades, mas deu pra perceber é que muita coisa que foi perguntando, só de perguntar não dá pra responder, porque exige conhecimentos anteriores. Igual eu perguntei que tipo de narrador, primeiro eu preciso trabalhar quais são os narradores. [...] De atividades, nós colocamos assim, primeiro, nós ficamos com uma polêmica em relação ao gênero. Se você vai fazer uma sequência didática, você tem que trazer alguma problemática, trazida dentro da sala, igual, um livro de receita, a estrutura e tudo mais. Aqui, o que poderia ter sido o pontapé inicial é falar: vocês vão faze a autobiografia ou biografia de um ídolo seu. [...] A biografia e o poema, essa eu achei difícil, contam dados passados, mas possuem trechos que remetem ao tempo presente, localizem essa parte. Na biografia tem verbos de estado, não sei se morrer é verbo de estado. -E no poema não acontece bem desse jeito, ele fala montava, montava. E no final, ele fala: eu não sabia que minha história era mais bonita que a de Robson Crusoé, esse verbo está no passado, mas ele faz um julgamento da infância dele. Mesmo estando no passado, ela tem um peso de presente. Mas eu coloquei essa questão, mas eu acredito que é bem difícil. Ficou um pouco falho, porque a única hora que utilizamos a mensagem foi quando pedimos para faze autorretrato. [...]

\section{TRECHO 3:}

PFC 2 - $O$ que significa as datas logo no início do texto; o personagem que a gente não soube dizer; por que ele foi considerado um dos maiores pilotos da história?; qual evento que marcou a corrida de São Marinho de 94?; relate a relação entre o texto 1 e o texto 2; quais as diferenças entre os textos; qual o tempo verbal presente no texto um. [...]

\section{TRECHO 4:}

PFC 3 - A gente começou com a apresentação da imagem, nessa imagem a gente ia investigar os conhecimentos prévios, através de perguntas, questionamentos. Levar a imagem para casa e buscar informações através de pesquisas com amigos, essas pesquisas viriam para casa e seria feito uma coletânea dessas informações com leituras, exposição oral e aí a gente ia começar a desvendar o mistério. Bom, nesse ponto aí, eu falei pra elas, até coloquei aqui, em cima da gravura, a produção de texto era antes da coletânea de informações. [...]

Nos trechos apresentados, podemos perceber que as atividades mantêm um mesmo percurso: acabam por elencar aleatoriamente várias questões sobre os textos, que demonstram ser tangíveis devido à sua capacidade de ler e interpretar o texto. Assim, a preocupação parece ter sido mais sobre quais aspectos mais difíceis a serem levantados como questão do que propriamente o ensino do gênero. Os trechos em análise apresentam indícios importantes para a avaliação formativa, uma vez que indicam dúvidas e questionamentos em relação àquilo que produziram. Assim, questões como (PFC 1) [...] porque exige conhecimentos anteriores [...] Se você vai fazer uma sequência didática, você tem que trazer alguma problemática, trazida dentro da sala [...] essa eu achei difícil, contam dados passados, mas possuem trechos que remetem 
ao tempo presente [...]; (PFC 2) [...] o personagem que a gente não soube dizer [...]; (PFC 3) [...] Bom, nesse ponto aí, eu falei pra elas, até coloquei aqui, em cima da gravura [...], acabam por revelar as dúvidas em relação aos aspectos elaborados e, também, começam a evidenciar certa reflexão sobre a elaboração da sequência didática como no trecho descrito em PFC1 em que o "se" expressa uma condição e o "tem" a certeza para que a SD realmente ocorra.

Esses aspectos são de extrema importância e considerados fundamentais, pois a partir dos questionamentos e das colocações dos colegas (a discórdia, o confronto de ideias) é o elemento que permitira ao professor formador organizar estratégias, assim como, pensar, quais os instrumentos ou maneiras para atingir o objetivo da elaboração da SD. Novamente, nos utilizamos das palavras de Dolz, Noverraz e Schnewuly (2004, p. 103): 'com efeito, o simples fato de 'fazer' - de se realizar uma atividade delimitada de maneira precisa - constitui um momento de conscientização do que está em jogo e das dificuldades relativas ao objeto de aprendizagem [...]" enquanto os autores referidos aludem às Capacidades de Linguagem, nos referiremos às Capacidades de Linguagem Docente (QUEVEDO-CAMARGO, 2011), que em relação ao objeto - à SD - se apresenta lacunar, fragmentado, demonstrando, assim, falhas em relação às Capacidades de Ação Docente quando mencionam suas dificuldades e incertezas quanto às atividades serem apropriadas ou não aos alunos (essa eu achei difícil); às Capacidades Linguísticas Docentes (o personagem que a gente não soube dizer); e às Capacidades Linguístico Discursivas Docentes (esse verbo está no passado, mas ele faz um julgamento da infância dele).

Nesse encontro, fica evidenciado um conflito do grupo, pois embora tivessem mencionado anteriormente que já elaboravam SD, e embora ainda não tenham adquirido consciência total disso, pode-se perceber pelo conteúdo das atividades desenvolvidas, que apenas organizaram várias questões que se referem aos textos, mas não em relação aos gêneros. Além disso, as Capacidades de Autoavaliação Docente começam a ser mobilizadas, isso vai (re)direcionando o curso e o próprio agir das PFC.

\subsection{O Conflito}

Antes de introduzir os novos dispositivos para o desenvolvimento das Capacidades docentes, o professor formador busca instigar os professores em formação continuada por meio de questionamentos. O objetivo é levá-los a refletir sobre aquilo que ainda não conseguiram perceber em relação à proposta de realização da SD. Na verdade, o que as professoras precisam compreender, e se sentirem instigadas e motivadas a querer aprender, corresponde nesse momento do curso ao uso do MDG como meio (ferramenta) para se construir a SD. Por isso, o professor formador realiza uma "bateria" de perguntas na busca de mediar às reflexões necessárias para a concretização da SD. 


\section{TRECHO 5:}

PF- Qual dessas questões propiciaria ao aluno produzir um texto autobiográfico, reconhecer. Capacitar o aluno reconhecer e produzir um texto autobiográfico. Vocês elencaram o gênero biografia, certo? Então, quais dessas questões propiciariam isso?/Quais dessas questões, quais dessas atividades tornariam propício pra criança aprender o gênero biografia em si?/Mas a discussão é justamente, qual é o gênero que eu vou trabalhar?/Então, a gente tem que esclarecer isso, é diferente eu perguntar qual é a intenção do texto de uma biografia gênero e qual é a intenção do autor dessa biografia. Sabe por quê?/O que eu quero que vocês pensem é isso: quais são as questões que eu to levando ao aluno?/Pode ser um, e o que mais? /Depende de onde ele está, quem produziu, não é a mesma que produziu pra um livro didático, então qual é a intenção?/ Onde ele tá sendo produzido?/ Qual é o objetivo? /O que ela quer fazer?/ Pra quem é produzido? /Eu preciso saber, o aluno precisa saber, certo? /Quando é produzido uma biografia?/ Em que momento? /É só depois que morre? /Quando tá em vida também?/ Precisa saber esses aspectos, tá./ Onde é produzido? Tá no jornal?/ Tá no livro?/ As condições de produção giram em torno dessas perguntas e outras, algumas mais, e depois eu vou passar pra vocês. /Aí eu vou pra uma outra etapa, agora no gênero biografia, eu tenho que explorar a infraestrutura geral do texto. /Quando a gente fala infraestrutura, nós estamos falando, por exemplo, a infraestrutura de uma casa, a infra é aquilo que está por baixo, a estrutura é aquilo que segura a casa, certo? /O que tá na base e os detalhes são as janelas, as .... então eu vou pro plano textual global. $/ O$ que é o plano textual global? /Aquilo qu eu olho e enxergo. /A biografia, ela tem vários parágrafos?/ Daí vem os tipos de sequência, são aquelas que a gente viu em duas aulas, exaustivamente. /Que tipos de sequência vão aparecer ali? /Porque a gente precisa trabalhar isso com o aluno, ele tem que perceber./ Daí vem os mecanismos de textualização. As escolhas lexicais, olha, um texto caminha sempre pra um grupo de palavra específico, que grupo de palavra que ele utiliza necessariamente?/ Bom.. vou deixar pra vocês. /Aí vem a coesão nominal, como ele se referencia ao sujeito que ele fala dentro do texto?/ Como que ele retoma esses nomes dentro do texto? /Ele repete quantas vezes Ayrton Senna? /O que que ele faz? /Ele substitui, corredor, vencedor, esse, piloto. /A coesão verbal, ou seja, que tipos de verbos ele utilizou?/ Verbos de estado?/ Verbos de ação? /O que que tá fazendo? /E os mecanismos enunciativos? \São as vozes, porque surgiu essa dúvida aqui, no grupo ali do meio. /Porque as meninas falaram: espera lá, ele é personagem?/ É uma narrativa? /Ele é personagem? /As vozes que aparecem, quando ele utiliza ele é um dos maiores corredores dos últimos tempos, quando ele utiliza isso, que voz tá parecendo ali? INão tá parecendo a voz de uma pessoa? /Você tá competindo comigo? (risos)/ E aí, né, que voz é essa? /De quem é essa voz? /Por que ele utilizou ((inint.)) dentro do texto?

Os questionamentos parecem bombardeantes, na verdade, eles só ocorrem, porque os professores em formação já tiveram como pré-requisito, além de outros cursos de formação continuada, uma noção sobre esses elementos questionados nas reuniões anteriores.

\section{TRECHO 6:}

PFC - Mais aguçando a curiosidade, o texto narrativo, a estrutura do texto narrativo. Um texto coletivo, o que eles pensariam?/Ele tem que identificar a biografia e ele tem que escrever?/Chega num momento que, nós, eu, esse texto de infância aqui, quando ele fala que: "a minha história", parece que num dado momento ali se confunde com a biografia, parece que você ia entrar. /Ele tá puxando 
pra descrição ali....Qual é a intenção?/ Qual é a função do texto? /Em relação a esse tipo de texto?/Eu tenho que ter essa intenção também? /De levar o aluno a produzir?/Não fomos muito pra gramática, explorando?/

Nesse pequeno trecho, podemos perceber como as professoras buscam relacionar os aspectos mencionados àquilo que produziram na produção inicial. Mas, o mais interessante é a forma como buscam contextualizar a situação à sala de aula e à preocupação com a aprendizagem do aluno. Assim, "ele" e "aluno" aparecem como a principal preocupação dos professores em formação. Ao questionar, mobilizam suas capacidades reais, com isso, confirmam a ausência de capacidades docentes sobre o próprio contexto - capacidade de ação docente (como em Qual é a intenção?/ Qual é a função do texto? Eu tenho que ter essa intenção também?/De levar o aluno a produzir?); capacidade linguística docente (Não fomos muito pra gramática, explorando?/); capacidade linguístico-discursiva docente (Chega num momento que, nós, eu, esse texto de infância aqui, quando ele fala que: "a minha história”, parece que num dado momento ali se confunde com a biografia, parece que você ia entrar. /Ele tá puxando pra descrição ali....).

\subsection{O Desenvolvimento da Capacidade de Autoavaliação Docente}

Ao final desse encontro a fala de um dos professores em formação chama a atenção:

\section{TRECHO 7:}

PFC - Você falou modelo didático, é esse que você tá definindo?

Toda a arguição do professor formador parece resultar, sem obviamente conseguir dimensionar em que medida, naquilo que desde início buscava estabelecer: consciência sobre o propósito dessa produção inicial. Podemos arriscar interpretações sobre o aspecto inquiridor, cujo propósito se concretiza à medida que conduz os professores em formação a desenvolver sua Capacidade de Autoavaliação Docente e, consequentemente, o desejo por ir a busca de resposta e, como resultado, o desenvolvimento de outras Capacidades de Linguagem Docentes.

\section{Considerações finais}

Como pudemos perceber por esta breve análise de um fragmento do que foi o curso como um todo, que existe uma complexa rede de implicações que impedem que o trabalho do professor se efetive na realidade. As dificuldades dos professores em formação em extrapolar aquilo que é visível aos textos e trabalhar aspectos sobre os gêneros e não somente o texto como pretexto têm suas raízes na sua própria história 
formativa. Assim, as capacidades docentes profissionalizantes por sua dimensão lacunar, às vezes inócua, deixam aspectos fundamentais à margem do que realmente é importante para o trabalho docente. Por serem um "feixe" de informações desencontradas e desconexas, teoria e prática parecem estar cada vez mais distantes, restando aos cursos de formação continuada entrelaçá-los. Porém, para que isso não se perpetue, é preciso que os cursos de formação continuada adquiram consistência e organização não só durante sua realização, mas de maneira prévia, talvez - sugerimos não como solução, mas como uma possibilidade - que isso se realize por meio de programas voltados ao desenvolvimento das Capacidades de Linguagem Docente a partir das capacidades autoavaliativas dos professores em formação.

\section{REFERÊNCIAS BIBLIOGRÁFICAS}

BRASIL. MINISTÉRIO DA EDUCAÇÃO CONSELHO NACIONAL DE EDUCAÇÃO: Diretrizes Curriculares Nacionais para a Formação de Professores da Educação Básica, em nível superior, curso de licenciatura, de graduação plena, 2001. Disponível em: http://portal.mec.gov.br/cne/arquivos/pdf/009.pdf acessado em $18 \mathrm{de}$ julho de 2012 às 20:00 hrs.

BRASIL, Ensino Fundamental de Nove Anos - orientações gerais - Ministério da Educação Secretaria de Educação Básica Departamento de Políticas de Educação Infantil e Ensino Fundamental - coordenação geral do ensino fundamental. MEC, 2004. Disponível

em: http://portal.mec.gov.br/seb/arquivos/pdf/Ensfund/noveanorienger.pdf

BRONCKART, Jean-Paul. Atividades de linguagem, textos e discursos: por um interacionismo sócio-discursivo. Tradução Anna Rachel MACHADO; Péricles CUNHA. São Paulo: EDUC, 1999.

Atividade de linguagem, discurso e desenvolvimento humano. Organização MACHADO, Anna Rachel e MATÊNCIO, Maria de Lourdes Meirelles; tradução MACHADO, Anna Rachel e MATÊNCIO, Maria de Lourdes Meirelles [ET all.]. - Campinas, SP: Mercado das Letras, 2006.

. O agir nos discursos: das concepções teóricas às concepções dos trabalhadores. Trad. Anna Rachel Machado e Maria de Lourdes Meirelles Matêncio. Campinas, SP: Mercado de Letras, 2008.

Ensinar: um "métier" que, enfim, sai da sombra. In: Linguagem e Educaçao: o trabalho do professor em uma nova perspectiva. Anna Rachel Machado e colaboradores: Vera Lúcia Lopes Cristóvão, Lilia Santos Abreu-Tardelli (orgs.); pósfácio Jean-Paul Bronckart. - Campinas, SP: Mercado das Letras, 2009.

BULEA, Ecaterina. Linguagem e efeitos desenvolvimentais na interpretação da atividade. Trad. Eulália Vera Lúcia Fraga Leurquin, Lena Lúcia Espínola Rodrigues Figueirêdo. - Campinas, SP: Mercado das Letras, 2010. 
COUTINHO, Maria Antónia. O interaccionismo sociodiscursivo: interpelações e desafios para as ciências da linguagem. Anais. V SIGET - Caxias do SUL, UCS, Agosto 2009.

CRISTÓVÃO, Vera Lúcia; STUTZ, Lídia. Sequências didáticas: semelhanças e especificidades no conteúdo francófono como L1 e no contexto brasileiro como LE. In: Szundy, P.T.C.; Araújo, J. C.; Nicolaides, C. S; SILVA, R. A. (orgs.). Linguística aplicada e sociedade: ensino e aprendizagem de línguas no contexto brasileiro. Campinas: Pontes Editores, 2011, v1, p.17-40.

DOLZ, Joaquim; GAGNON, Roxane; DECANDIO, Fabricio Roberto. Uma disciplina emergente: a didática das línguas. In: NASCIMENTO, E.L.(Org.) Gêneros textuais: da didática das línguas aos objetos de ensino. São Carlos: Claraluz, 2009, p. 19-51.

FAITA, Daniel. Gêneros de discurso, gêneros de atividade, análise da atividade do professor. In: MACHADO, A. R. O ensino como trabalho: uma abordagem discursiva. Londrina: EDUEL, 2004, p. 55- 81.

FELDMAN, Daniel. Trienta y seis capacidades para lá actividad docent em escuelas de educación básica. Disponível em: http://pt.scribd.com/doc/93881321/36CAPACIDADES-DOCENTES Acessado em 14 de maio de 2012.

FRIEDRICH, Janette. Lev Vigotski: mediação, aprendizagem e desenvolvimento: uma leitura filosófica e epistemológica. Trad. Anna Rachel Machado e Eliane Gouvêa Lousada. - Campinas, SP: Mercado das Letras, 2012.

GAGNON, R. Former à enseigner l'argumentation orale: De l'objet de formation a l'objet enseigne en classe de culture generale. 2010. $490 \mathrm{f}$. Tese (Doutorado em Didactique). Faculte de Psichologie et des Sciences de l'Education. Universite de Geneve, 2010.

HOFSTETTER R.; SCHNEUWLY, B. Savoirs en (trans)formation. Au coeur de l'enseignement et de la formation. In: HOFSTETTER, R.; SCHNEUWLY, B. (Org.). Savoirs en (trans)formation. Au coeur de l'enseignement et de la formation. Bruxelles : De Boeck, Coll. Raisons Educatives, p. 7-40, 2009.

LEONTIEV, Alexis N. O desenvolvimento do psiquismo. Lisboa: Livros Horizonte, 1978.

MACHADO, Anna Rachel. O ensino como trabalho: uma abordagem discursiva. Londrina: Eduel, 2004.

et all. Relações entre linguagem e trabalho educacional: novas perspectivas e métodos no quadro do interacionismo sócio-discursivo. In: MACHADO, Anna Rachel e colaboradores; Vera Lúcia Lopes Cristóvão, Lilia Santos Abreu-Tardelli (orgs.); pósfácio Jean Paul Bronckart. - Campinas, SP: Mercado das Letras, 2009.

; BRONCKART, Jean Paul. (Re)configurações do trabalho do professor construídas nos e pelos textos: a perspectiva metodológica do Grupo ALTER-LAEL. 
In: . In: MACHADO, Anna Rachel e colaboradores; Vera Lúcia Lopes Cristóvão, Lilia Santos Abreu-Tardelli (orgs.); pósfácio Jean Paul Bronckart. - Campinas, SP: Mercado das Letras, 2009.

; LOUSADA, Eliane Gouvêa; FERREIRA, Anise D'Orange. O professor e seu trabalho: a linguagem revelando práticas docentes. Campinas, SP: Mercado das Letras, 2011.

MEC: orientações gerais - Rede Nacional de Formação Continuada de Professores da Educação Básica. Coordenação Lydia Bechara, 2005.

NASCIMENTO, Elvira Lopes. Características multimodais da ação docente: ferramentas para a compreensão do trabalho realizado. Anais. CELLI - Colóquio de Estudos Linguísticos e Literários. UEM. 2012.

QUEVEDO-CAMARGO, Gladys. Avaliar formando formar avaliando o (futuro) professornde língua inglesa: elementos para um construto. 2011. 362 fls. Tese (Doutorado em Estudos da Linguagem) - Universidade Estadual de Londrina, 2011.

PNE 2010/2020 - Plano Nacional da Educação http://portal.mec.gov.br/arquivos/pdf/pne.pdf Acessado em maio/ 2012 às 14 hrs.

SCHNEUWLY, Bernard; DOLZ, Joaquim. Gêneros orais e escritos na escola. Trad. E org. Roxane Rojo e Glaís Sales Cordeiro. - Campinas, SP: Mercado das Letras, 2004.

STUTZ, Lídia. Sequências didáticas, socialização de diários e autoconfrontação: instrumentos para a formação inicial de professores de ingles. 2012, 383 f. Tese (Doutorado em Estudos da Linguagem) - Universidade Estadual de Londrina, 2012.

TARDIFF, Maurice. Saberes docentes e formação profissional. $9^{\mathrm{a}}$ Ed. Petropólis: Vozes, 2008. 